\title{
D.A. Radoushinsky
}

\author{
THE IMPACT OF PUBLIC-PRIVATE PARTNERSHIPS \\ ON THE DEVELOPMENT OF COMMUNICATIVE ENVIRONMENT \\ OF INNOVATIVE ECONOMY
}

\author{
Д.А. Радушинский \\ ВОЗДЕЙСТВИЕ ГОСУДАРСТВЕННО-ЧАСТНОГО ПАРТНЕРСТВА \\ НА РАЗВИТИЕ КОММУНИКАТИВНОЙ СРЕДЫ \\ ИННОВАЦИОННОЙ ЭКОНОМИКИ
}

The paper examines the impact of public-private partnership on the economy growth factors associated with communications and the possibility of the existing PPP centers to run functions of communication centers. The study draws a model of public-private partnership system based on the background of causing one other economic growth factors that are related to the open communicative innovation economy. The model shows the appearance of axis «Communication» - «partnership» - «innovation» - «development» on the basis of a longterm relationship of trust within the PPP between the subjects of the state and business. This relationship enhance the mutual dependence of subjects and the intensity of the exchange of information and thus become, communication - active. As part of the bunch «communication» - «partnership» the features of the mutual initiative in PPP-projects and the essential nature of PPP are described. The characteristics and objectives of PPP development in Russia are examined on the background of analysis of partnership between the state and the private sector in a number of economies in the world. The medium and long term factors are revealed, preventing the increase of the level of involvement of private funds - both from domestic and foreign investors - in relation to public spending, and in relation to GDP. The importance of the international dimension of PPP development in Russia on the basis of the available Russian experience is pointed: concession agreements with foreign investors, are historically one of the key tools to attract foreign investment. It is concluded that in the view of innovative development of Russian economy the development of PPPs strategies should include orientation on the external international partners. An approach is suggested to the study of issues of coordination of the development of PPPs with long-term priorities of innovative development of the economy through the system of communication centers. An assessment of compliance is made of the functions ran by PPP centers operating today to the set of functions and features that are related to the concept of communication centers of innovation infrastructure. The study suggests a method of calculation of the integrated economic effect from the involvement of foreign partners into the joint activity on creation of an innovative product under the PPP. It was concluded that such an effect will be one of particular indicators of the effectiveness of communication in innovation, which arises due to the international nature of cooperation within PPP.

PUBLIC-PRIVATE PARTNERSHIP; COMMUNICATION ACTIVE RELATIONSHIPS; COMMUNICATION CENTER OF THE INNOVATION INFRASTRUCTURE; INNOVATION SYSTEM; FOREIGN INVESTMENT.

Рассматривается влияние государственно-частного партнерства на факторы экономического роста, связанные с коммуникациями, и возможности выполнения существующими центрами ГЧП функций коммуникационных центров. На основе последовательности взаимодействия обусловливающих друг друга факторов экономического роста построена модель развития системы государственно-частного партнерства в открытой коммуникативной экономике. Модель показывает возникновение оси «коммуникации - партнерство - инновации - развитие» на основе долгосрочных доверительных отношений в рамках ГЧП между субъектами государства и бизнеса, которые повышают взаимную зависимость, интенсивность обмена информацией и становятся, таким образом, коммуникационно-активными. В рамках оси «коммуникации - партнерство» рассмотрены особенности, связанные с обоюдной инициативой в проектах и черты сущностной стороны ГЧП. Проанализированы характеристики и задачи развития ГЧП в России на фоне особенностей партнерства государства и частного сектора в ряде мировых экономик. Выявлены факторы среднесрочного и долгосрочного характера, препятствующие повышению уровня привлечения средств отечественных и иностранных инвесторов - по отношению к государственным тратам и к ВВП. Отмечена важность международного аспекта развития ГЧП в России: исходя из имеющегося российского опыта, концессионные соглашения с участием иностранных инвесторов 
являются одним из ключевых инструментов привлечения зарубежных инвестиций. Сделан вывод, что в целях инновационного развития ориентацию на развитие ГЧП с включением внешних партнеров целесообразно сохранять. Предложен подход к исследованию вопросов координации развития ГЧП с долгосрочным приоритетом инновационного развития экономики через систему коммуникационных центров. Произведена оценка соответствия функций действующих сегодня центров ГЧП тому набору функций и характеристик, которые отнесены к концепции коммуникационных центров инновационной инфраструктуры. Предложен способ расчета интегрального экономического эффекта от вовлечения иностранных партнеров в совместную деятельность по созданию инновационного продукта в рамках ГЧП. Сделан вывод, что подобный эффект представляет собой один из частных показателей эффективности коммуникаций в инновационной деятельности, обусловленный международным аспектом сотрудничества в рамках государственно-частного партнерства.

ГОСУДАРСТВЕННО-ЧАСТНОЕ ПАРТНЕРСТВО; ПУБЛИЧНО-ЧАСТНОЕ ПАРТНЕРСТВО; КОММУНИКАЦИОННО-АКТИВНЫЕ ОТНОШЕНИЯ; КОММУНИКАЦИОННЫЙ ЦЕНТР ИННОВАЦИОННОЙ ИНФРАСТРУКТУРЫ; ИННОВАЦИОННАЯ СИСТЕМА; ИНОСТРАННЫЕ ИНВЕСТИЦИИ.

Introduction. At present, in the global and domestic economy, the trend to tighten relations between the state and private business in order to work together in solving economic problems has been intensified. The government and private companies, banks, international financial institutions and other entities interact widely, jointly solving new tasks.

In the modern sense a public-private partnership is the institutional and organizational alliance of state (or municipal authority) and business which accommodates tangible and intangible resources of both parties on a mutually beneficial contractual basis for the implementation of socially important projects and programs in a wide range of areas: from basic industries and $\mathrm{R}$ $\&$ D to delivery of public services [1].

The problems solved by state are related as to current public service and as to long-term development of the economy through the availability of infrastructure and support for innovation. Notably, the most funds spent through PPP in all countries where it is applied, is spent for public facilities (transport, utilities, social infrastructure, cultural facilities, historical and architectural monuments, and so on) and for public services - repair, reconstruction and maintenance of public facilities, cleaning of territories, public utilities, education, health and sports. PPP today is also widely used to finance applied innovation projects and innovation infrastructure. However, in some areas of the state responsibility - defense, law enforcement, basic science, legislation and some other areas PPP is almost never used. In the sphere of the development of natural resources, PPP is implemented in the form of concessions and PSAs, which are most common in developing countries.
PPP is studied in detail from different perspectives by foreign Russian scientists such as the Varnavskiy V.G., Vilisov M.V., Glukhov V.V., Deryabin M.V., Delmon J., Yescombe E.R., Petrov A.N., Sazonov V.E., Iastrebov O.A., and many others (for example [2-9]). In 2015 a law on PPP was legislated in Russia. It is worth noting some general studies published in recent years [9-11]. The paper of Y. Yemelyanov [9] is devoted to various aspects of the impact of the investment activities of the PPP on innovative development, including the development and adaptation of new growth points in a particularly promising technology. Also this study discloses an innovative effect, resulting from the implementation of some successful PPP projects in a number of countries and regions of the world, including the CIS countries. The paper of A.K. Kazantsev and D.A. Rubvalter [3], reprint of their 2009 study, is devoted to a comprehensive study of the mechanisms and forms of PPP, used for financing innovative activities. It analyses the possibility of transferring a number of successful international practices (from USA and other OECD countries) to Russia, also it presents a number of new project initiatives, elaborated especially for the advanced procurement of PPP in the Russian context. The paper edited by G.A. Machovickova and N.F. Efimova [10] contains a generalized theoretical information on PPPs, and analysis of completed and ongoing examples of implementation of PPP projects in the world and in Russia. The paper Ed. by E.R. Yescombe [11], inter alia, considers aspects of PPPs development in different countries, PPP disadvantages; this paper describes investment decisions and public tenders procedures under PPP, details the practical aspects of the financing 
of private companies entering into PPP agreements and more.

However, nor in the known works of Russian writers, nor in the works of foreign authors the questions of the relations between the communicative nature of the innovation economy (knowledge economy) and the content of publicprivate partnerships are not staged, the corresponding dependencies has not been studied in applied works.

Statement of research objectives. The objectives of this study is to analyze the mechanisms of intensifying information communications in the knowledge economy with the help of PPP and to evaluate the state of competence of PPP development centers at different levels, which operate today, in comparison with the conceptual functions of communication centers of innovation infrastructure, (the elements of the development of innovative, communicative economy).

The methodology of the study. The study is based on the assumption of the special role played by the spread of public-private partnership for the development of innovation systems at regional and national level. Particular attention is paid to the potential of attracting foreign investment, which forms the international aspect of the formation of the PPP relations in Russia, having both historical and important perspective meaning.

The research unit of this article uses the idea of today's dynamic type of economic system, which connects with the concepts of «knowledge economy», «communication», «information», «innovative» economy and also includes analysis of the inducements of the parties and the institutional PPP values. A score-rating approach and the method of expert evaluations were applied.

The role played by the PPP in modern communicative economy. PPP projects most widely spread over the world in the last 20-25 years, due to the possibility to take advantage of different forms of ownership. Through PPP government has the opportunity to fulfill social functions by implementing the public interest, and private companies receive the sources of growth of profit, reputation, and market value.

The basis for cooperation of PPP participants is the coherence of their objectives. Each party of PPP, according to their characteristics and objectives, make certain contributions to joint projects. From the business is expected to provide financial resources, professional expertise, innovative technologies, efficient management. The state ensures the reliability of the projects through the provision of guarantees, tax and other benefits and by its own financial resources in a certain amount [12, p. 103]. A lot of investment PPP projects in Russia stopped without substantial government participation. Thus, the state guarantees at the federal level, or taking into the parties the federal budget (Investment Fund) - in PPP projects has been an important condition of implementation of such projects in Russia in the 2000s, which as a deterrent has been mentioned in the field study at 2010 [13].

PPPs have a long-term relationships, higher interdependence of the partners, joint risk-taking on the contrary to the other established form of government and business relations, public ordering (purchase of goods, services outsourcing from a private business entities). A typical effect of a PPP is that the state shifts focus to its activities from the specific problems of construction and operation to the administrative and control functions. Delegating through PPP executive functions to businesses, government agencies focus on control functions, regulation, compliance with the public interest. Operating risks are redistributed towards business parties, while the government continues to carry strategic risks.

Successful examples of PPP in the innovation sector of the economy (mostly abroad [14]) also indicate that the partnership with the private sector allows the state not only to solve the problems in the traditional areas, but also on the actual new directions.

The effect and the condition of mutual credit and confidence accompanying the delegation's of state functions to business leads to the situation where the state is no longer «above» the market players (the position in relations of «planning system» - «market system», in which the latter has subordinate status [15]). In the new situation state and business come relatively equal, businesspartners-like relationships. Long-term relationship of trust within the PPP between the state and business entities increase the mutual dependence and the intensity of the exchange of information and thus become, communication - active. 


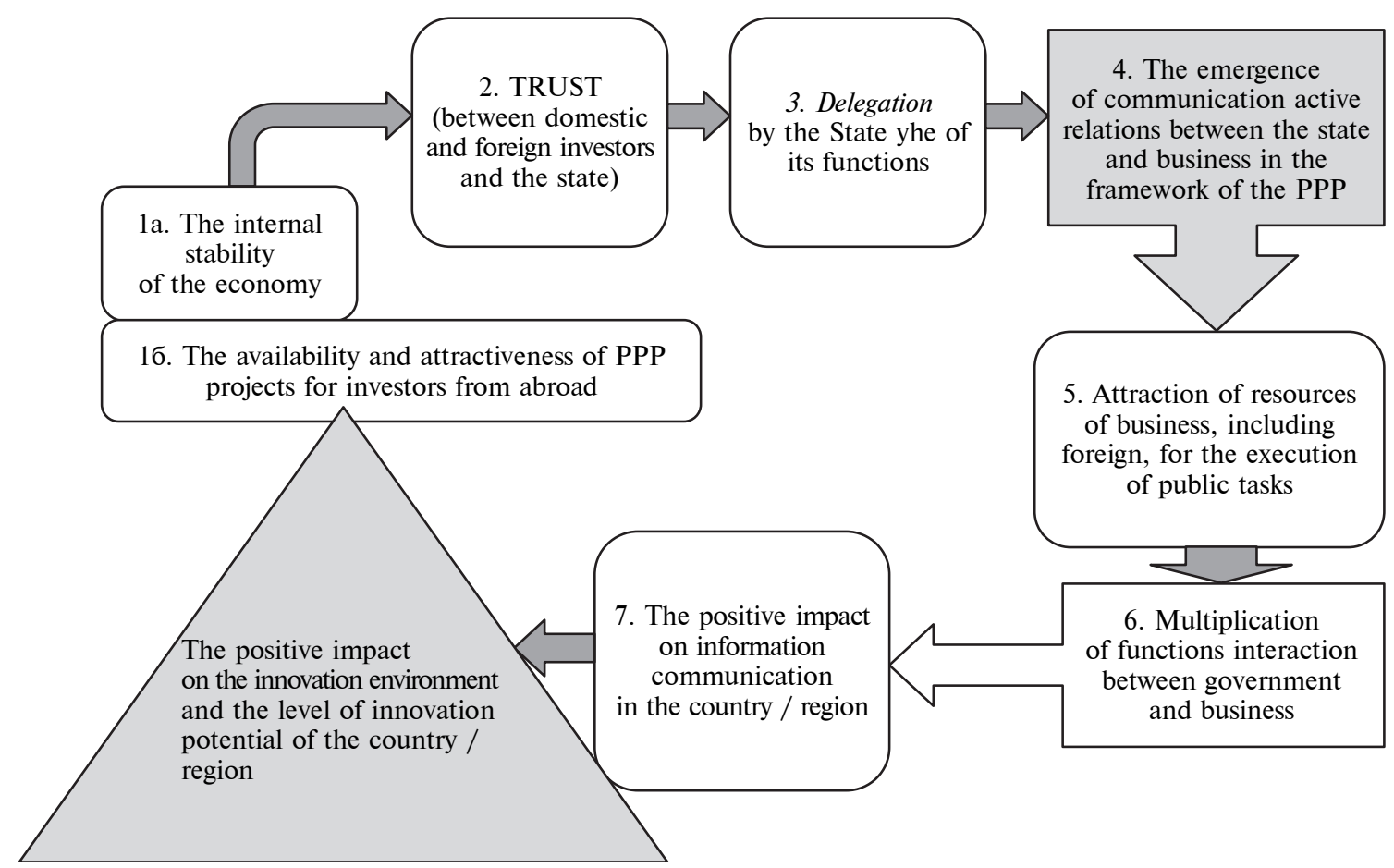

Fig. 1. Model of the impact of PPPs on the relationship of growth factors in an open communicative economy

In turn, we recall that one of the definitions of the modern dynamic type of socio-economic system, aimed at innovative development, through the creation, dissemination and use of knowledge is «communicative (or communication) economy.» The source of «innovation goods» and the primary means of accelerating and improving the quality of economic growth in such a dynamic system is a modern information communications. As noted in a number of the classic definitions of the innovation (information) socio-economic system («knowledge economy»), it is the intensity of the exchange of information / communications, allowing to convert («materialize») the knowledge into innovation products [16-21].

There can be built the following model of relations in a communicative economy on the basis of PPP (see. Fig. 1).

The action of the model is as follows. The developed system of public-private partnership demonstrates the presence of a number of premises and causing one other growth factors that are related to communication in information economies. Macroeconomic stability, on the one hand, and the availability and attractiveness of PPP projects for investors from abroad, promote the establishment of relations of trust $\mathrm{t}^{1}$ to the state. When the state begins to delegate some of it functions under the PPP deals, this strengthens the active communication and relations within the longterm joint projects. Attracting new resources on both sides allows to expand the interaction that stimulates further information communications and increases the innovative potential of the territory. In turn, the innovation potential attracts the foreign investors and becomes the most important factor in the further sustainable development of a country or a region. The axis arises «communication» - «partnership» «innovation»- «development».

As part of the bunch «communication» «partnership» should be listed at least two features:

I) Mutual initiative. Information interaction and relatively high degree of freedom of subjects are the key features of the communication economy. They make natural the process of initiation by the both sides, state and business («Market») of joint projects. In this connection, in the current

${ }^{1}$ It should be noted that the decisive role of the phenomenon of trust in the successful interaction of the subjects of marketing systems has been repeatedly pointed by scientists marketers (P. Doyle, F. Kotler, J. Krevens, G.L. Bagiev et al., Ibid., for example [22]). 
legislation on PPP, for example, provides a mechanism for private initiative (unsolicited proposals), which regulates the procedure for work with the initiatives of private investors.

2) The form and nature of the PPP. It should be borne in mind that communication active relations and partnership of government and business in the advanced innovation economies take a form as of PPP, as well as long-term public order (administrative contracts), and effective government institutions involved in the provision of public services as well.

The essence of «partnership» is manifested in the fact that there is business and government cooperation in the realization of common objectives relating to the provision of public services through the mechanisms of acquisition of the business income in the form of taxes and the subsequent spending of these funds either through PPP, or through a government order, or to the maintenance of government structures involved in the provision of public services. If businesses and individuals pay more taxes, that government agencies tend to provide public services on their own. In countries where the level of taxation of business and individual taxes are less, the state has fewer structures for the provision of public services and more actively «purchases» these services from the private sector (see also below).

Characteristics and objectives of PPP development in Russia on background characteristics of partnership between the state and the private sector in a number of economies in the world. The form of the PPP (PPP - public private partnership) is used more or less widely in specific countries, which identify today with innovative economy [23-25], depending on the prevailing historical patterns of interaction between business and the state in the territory and tax legislation. The vast use of PPP contracts is adherent to Anglo-Saxon legal system where the partnerships including in small and medium-sized projects is called PPP. At the same time, for example, in the French legal system, the concession contract (including in areas such as education, science, medicine), is legally referred to as administrative contract (government ordering), while the form of PPP affects only the large-scale infrastructure projects.

Spread of PPP form is related to public opinion, the tax level and the prevailing perceptions of the population of the state's role in the provision of services [26]. In European countries, where the highest percentage of GDP is redistributed through the state budget (Finland - $58 \%$, France - 57, Austria - 53, Sweden $50 \%$ ) [27], the population expects the state in exchange for the high level of taxes collected will itself provide most of the services related to transportation, education, health care of the population, etc. PPP projects in these countries face with a serious opposition of the population, and the free provision of services by public bodies dominates.

In the countries of the Anglo-Saxon legal system, where historically high priorities have personal initiative of citizens and competition, the level of income tax and profit tax of are lower (UK, Ireland, USA, Australia), and more significant part of the public services is provided by private business under state supervision . Thus, the state in a number of countries (primarily the United Kingdom, the United States) is ready to transfer to the private sector through PPP the largest volume of public functions that became known as semi-privatization [28].

PPP development in Russia has its own characteristics. The share of GDP redistributed through the budget (in 2015 about $38 \%$ [29]), in Russia is more closer to the United States (36.5\%) and the UK (40\%) than to Continental Europe countries (Germany - $43 \%$ [30], France - $57 \%$ ) and Scandinavia (Sweden $50 \%$, Finland - $58 \%$ ), however, in Russia - as in France or Scandinavia - most of the public services are provided by public agencies or on the basis of the state ordering. The spread of PPPs still has a relatively small scale.

Ongoing projects in Russia differ in their structure from the most developed countries, where the basis of PPP agreements is constituted by infrastructure projects, while the volume of PPP expands in innovative industries. The PPP agreements are not conducted in innovation areas in Russia, the most significant private investments in PPP has been made in the mining industry, where since the 1990s acts number of major PSAs (production sharing agreements). The PPP in infrastructure projects is developing (for 2015 in Russia at various stages of implementation the number of PPP projects is about 1300: 15 - at the federal level, 191 regional, 1100 - Municipal), [31, p. 6] but still has a relatively small scale compared with several other countries. 


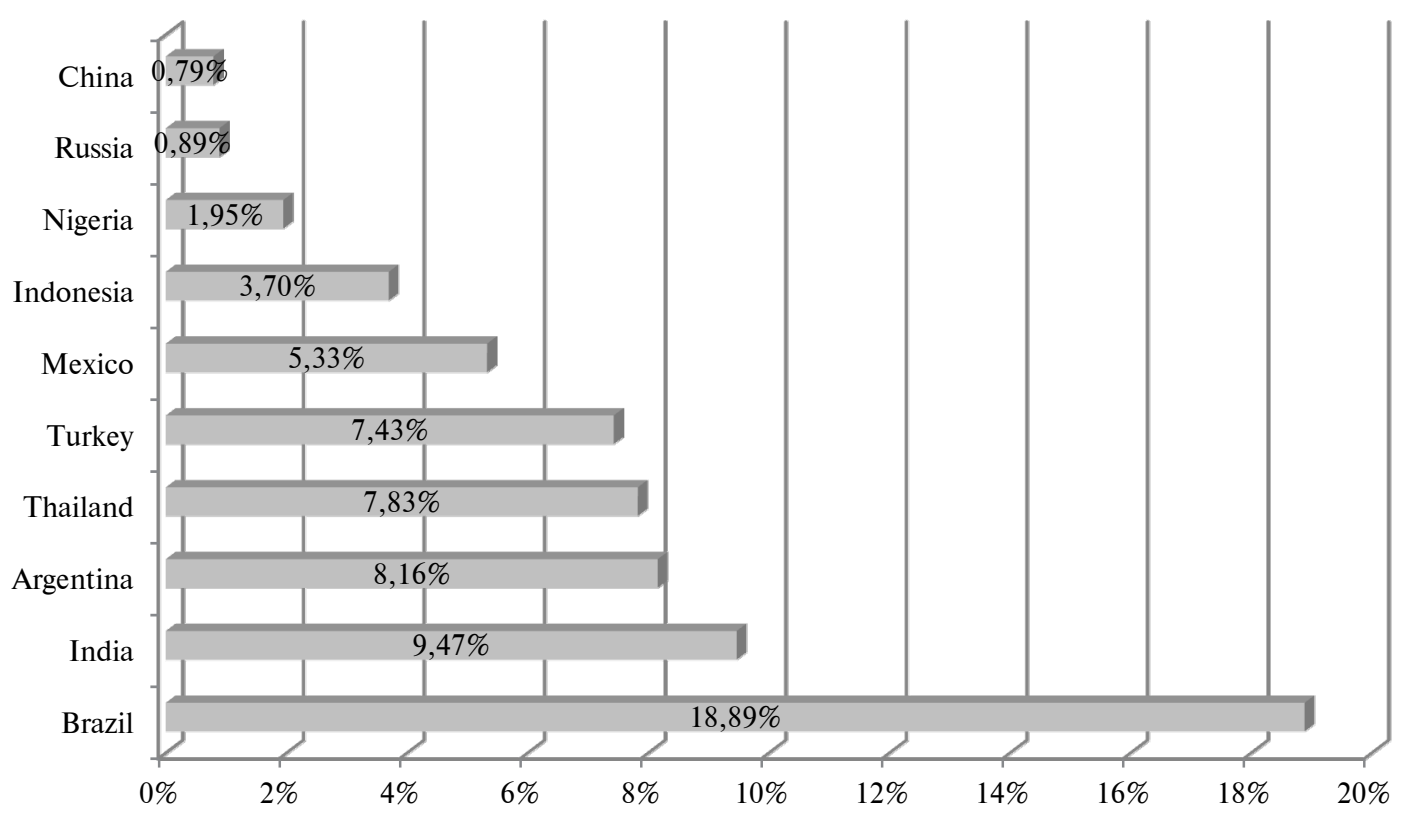

Fig.2. The ratio of private investment in PPP projects to nominal GDP. Source: [30, p. 9] - according to the World Bank, the IMF, Rosstat, calculations of PPP Development Centre.

Let's take a look at private investment in PPP projects to nominal GDP, which for Russia in 2015 is less than $1 \%$. Not only in the most developed economies, but today and in many countries with similar patterns and levels of investment in infrastructure in the PPP principles percentage ratio of the volume of private investment to nominal GDP is much higher (see. Fig. 2).

Moreover, in Russia the average share of the state budget funds (including those from the Investment Fund of the Russian Federation), in the joint PPP projects is above average being close to $50-60 \%$ vs. $20-35 \%$ average in the world, [9-11]. In these circumstances, the experts deem appropriate efforts aimed at increasing the level of involvement of private funds - both domestic and foreign investors - in relation to public spending, and in relation to GDP. In Russia, the latter ratio in order to achieve a balance within the process of attracting infrastructure investments on the principles of PPP must reach a level of around $4-5 \%$ of GDP, as estimated [31, p. 9] $(4-5$ times greater than the current level, see. Fig. 2).

On the way to perform this task there is a number of obstacles having a medium-term (pertaining to the financial crisis and the sanctions regime) as well as long-term, institutional character. In the medium term an indefinite period of the financial «sanctions», the difficulties experienced domestic financial market, and the possible defaults could undermine as indicated $[31$, p. 6$]$, the credibility of the regional and municipal authorities to concessionaires. In the long term, the most significant are the institutional problem of trust on the part of private partners - apprehension of high costs of corruption and limitations on the participation of foreign capital.

The task of raising the level of involvement of private funds - both domestic and foreign investors - in relation to public spending, and in relation to GDP by PPP is a matter of qualitative improvement of relations. This formal quantitative increase in the number of PPP agreements in Russia, as in the traditional areas of application as well as in the sphere of innovation risks only become a new form of acting system of distribution of state funding and state property management [32]. In the case of quantitative increase, there may be an increase in the share of budgetary funds accumulated in PPP contracts, but the volume of attracted private funds did not significantly increase, as there will no trust relations established, the qualitative factors wouldn't enhance communication intensity. 
Coordination of PPP with long-term priorities of innovative development of the economy through the system of the communication centers. Innovative development is based both on the own achievements, and the successful development of exchange and borrowing of advanced innovative technologies and organizational experience. It is believed that the involvement of technology and expertise is most likely a result of foreign direct investment, and PPP has forms that provide opportunities for direct investment. However, even if only portfolio and financial investments of institutional investors, known infrastructure companies from abroad are carried out within the PPP, the level of innovation in the regions where these international projects are implemented, indirectly will increase [33].

Historically, much of PPP development in Russia was due to the involvement of foreign private capital. Concessions with the involvement of foreign companies have been widely used in Tsar Russia, during the NEP, the period of industrialization in the Soviet Union. Concession agreements and production sharing agreements (PSAs) with foreign companies were concluded in the 1990s. However, assessing the effectiveness of the latter are rather contradictory ${ }^{2}$.

In general, based on the available Russian experience, concession agreements with foreign investors, it is one of the key tools to attract foreign investment [34]. In this regard, it is worth to note that in contrast to the Law on Concessions, 2005 [35] in the Law on PPPs adopted in 2015 [35] only the Russian legal entity may act as a private partner. The Law on PPPs so today is focused on partners residents, while the Law on Concessions is open to the foreign investors.

To date, the involvement of foreign investors is complicated by the financial crisis and political contradictions. Loss of access to direct and portfolio investment from Western countries the traditional partners (Germany, the EU as a whole) come to a need to find them on the markets of China and other emerging economies of Asia, which have the surpluses in trade balance of payments. [37] Experience of 20142016 showed that the attraction of direct and

${ }^{2}$ Conditions and results of executing the largest number of PSAs in Russia regularly received negative assessments of the Audit Chamber. portfolio investments and credits from China and the leading countries - exporters of oil (especially the so-called «Gulf monarchies») remains today a difficult task for Russian companies and state.

Despite these complexities, focus on the development of PPPs should include external partners in order to keep the innovative development expedient. Within the framework of the provisions of the presented model (Fig. 1) on the attractiveness of the economy to foreign investors affects communication active nature of PPP, providing a positive impact on the innovation environment and innovation potential of the country / region, and then causing the internal stability of the economy. Coordination of PPP development process with the long-term priorities of innovation development of economy it is advisable to carry out on the basis of the communication aspects of PPPs.

In Russia PPP centers today are working on a number of levels. The PPP-centers in cross sectoral Ministries of Regional Development, Economic Development and Finance cooperate with Vnesheconombank and the Investment Fund of the Russian Federation on strategic planning and management of the implementation of PPP projects of national and regional scales, which are based on the investment and construction projects, mainly in the form of a concession. At the regional and municipal level are local centers - for example, public-private partnership projects department of the Committee for Investments and Strategic Projects of St. Petersburg Government.

Existing regional, cross - sectoral and departmental PPP development centers, performing the tasks of activation of private investments in joint projects with the government, are important actors of the existing innovation infrastructure.

From the point of view of the author, the current PPP centers can be considered as a regional and interregional-and-coordinating communication centers of innovation infrastructure. In accordance with the author's concept [38], the primary function of communication center in the socio-economic system with a given level of development is the organization of interaction with the representatives of socio-economic systems with the same or higher level of development in order to obtain from them 
(through the exchange, purchase, etc.) advanced technology, skills and other kinds of valuable information and knowledge.

Communication centers of innovation infrastructure for today is the scientific concept, which implementation needs to be further verified at technical and economic level. However today, the part of their intended functions are already implemented by a number of existing innovation infrastructure subjects (actors) at the federal and regional levels, including the PPP centers, scientific and industrial centers of large companies, research and innovation centers at universities.
In this study, we consider it appropriate to assess the conformity of the functions of PPP centers operating today to the set of functions and features that are related to the concept of communication centers of innovation infrastructure. This assessment has been made by a number of experts with the using of the score-rating system. The tab. 1 (see. below) shows in column 2 the basic and the additional characteristics (functions) of communication centers, in columns 4-6 shows matching scores from 0 to 5 (by expert assessment), column 3 shows the rating of the given characteristic in percentage.

Table 1

Conformity assessment of conceptual characteristics (functions) of the innovation infrastructure communication center to the functions of existing cross - sectoral, regional and departmental PPP centers.

\begin{tabular}{|c|c|c|c|c|c|c|}
\hline № & $\begin{array}{c}\text { Basic and additional characteristics } \\
\text { (functions) of the communication center } \\
\text { of innovation infrastructure }\end{array}$ & $\begin{array}{c}\text { Rating } \\
\text { of the } \\
\text { characteristic, } \\
\%\end{array}$ & $\begin{array}{l}\text { Cross - } \\
\text { sectoral }\end{array}$ & Regional & Departmental & Comments \\
\hline 1 & 2 & 3 & 4 & 5 & 6 & 7 \\
\hline 1 & $\begin{array}{l}\text { intensively involved in the process of } \\
\text { «diffusion of innovations» }\end{array}$ & 15 & 2 & 3 & 3 & $\begin{array}{l}\text { Coordinates the } \\
\text { process of «diffusion» }\end{array}$ \\
\hline 2 & $\begin{array}{l}\text { integrates directly interacting units that } \\
\text { are grouped geographically which is } \\
\text { expedient for the informal transmission } \\
\text { of «tacit knowledge» }\end{array}$ & 10 & 0 & 2 & 2 & $\begin{array}{l}\text { Does not have in } \\
\text { its structure the } \\
\text { scientific and industrial } \\
\text { organizations }\end{array}$ \\
\hline 3 & $\begin{array}{l}\text { it has the organizational and managerial } \\
\text { authority }\end{array}$ & 25 & 5 & 2 & 2 & $\begin{array}{l}\text { According to the } \\
\text { current practice }\end{array}$ \\
\hline 4 & $\begin{array}{l}\text { international character due to } \\
\text { orientation towards collaboration with } \\
\text { foreign partners }\end{array}$ & 15 & 3 & 2 & 1 & $\begin{array}{l}\text { Depending on the } \\
\text { ability to influence } \\
\text { on foreign partners }\end{array}$ \\
\hline 5 & $\begin{array}{l}\text { focus on actual mechanisms and legal } \\
\text { forms of public-private partnership } \\
\text { (PPP) }\end{array}$ & 10 & 5 & 3 & 4 & $\begin{array}{l}\text { Depending on the } \\
\text { proximity to the } \\
\text { developers of legislative } \\
\text { norms }\end{array}$ \\
\hline 6 & $\begin{array}{l}\text { a significant PR-component that can } \\
\text { engage the «creative class» within the } \\
\text { country and foreign business partners in } \\
\text { the communication center activities }\end{array}$ & 15 & 1 & 2 & 0 & $\begin{array}{l}\text { The function } \\
\text { corresponds to specific } \\
\text { identi-fiable projects } \\
\text { in the regions }\end{array}$ \\
\hline 7 & $\begin{array}{l}\text { providing humanitarian and business } \\
\text { cooperation with the state and Russian } \\
\text { military structures, including the } \\
\text { structures the Rear the Russian Armed } \\
\text { Forces }\end{array}$ & 10 & 0 & 1 & 0 & \\
\hline & Total grade & $100 \%$ & 2,65 & 2,15 & 1,70 & \\
\hline
\end{tabular}


Thus, the most competent in carrying out the functions of communication centers of innovation infrastructure today can be regarded the crosssectoral PPP centers in the Ministry of Regional Development, Economic Development, Finance (total grade 2.65 out of 5 points). This assessment of their level of compliance enables them to perform the conditional tasks of coordinating communication centers at the interregional and cross-sectoral level.

Existing regional PPP centers can now carry out more than $40 \%$ of the conceptual functions of communication centers of innovation infrastructure (total grade 2.15 of 5). This assessment should be recognized as inadequate to carry the competence of communication centers of innovative infrastructure in the regions (Federal districts). This level should be the most high (at least $90 \%$ ) in order to be able to support local projects at the appropriate level. The full development of the communication component for regional PPP centers implies the need to develop the remaining set of functions (functions of performance competencies) within the newly established structural units within regional centers PPP or through specially created new structures.

As to regard to the departmental centers, for them it would be optimal to have a total grade of about 2.5 out of 5 , which would allow them to play a coordinating communication role within their industries at a sufficient level. However, the current total grade (1.7 of 5), means the feasibility of reinforcing of competencies in a number of functions they perform, such as «collaboration with foreign partners», «PRcomponent».

Such issues as the further evaluation of the current levels of competence of the existing subjects of innovation infrastructure, including PPP development centers, as well as justification of sufficient and target levels of the implementation by the existing subjects of innovation infrastructure of conceptual functions of communication centers are subject to further methodological and practical analysis.

The approach to the calculation of the integral economic effect from the involvement of foreign partners in joint ventures to create an innovative product under the PPP. One of the basic characteristics of the communication centers is its focus on international cooperation.
To assess the PPP instruments opportunities in attracting foreign partners for joint innovation it is appropriate to measure the economic effect of the integral involvement of foreign partners in joint ventures to create an innovative product under the PPPs. Such an effect will be one of particular indicators of the effectiveness of communication in innovation, which arises due to the international aspect of cooperation within the PPPs.

It should be understood that the measurement of this effect in the current conditions, while the experience of involving foreign partners in PPPs in Russia has a single nature, will be quite evaluative. This measurement is based on an attempt to quantify the number of quality indicators, including reputational effect, reflecting the attraction for cooperation (may be known) international company compared with the implementation of a project to create an innovative product under the PPP involving domestic partner.

In addition, for such comparisons one must have a valid data on the financial results of the project in different conditions. Once such data is obtained, then for calculation of the integral economic effect of the involvement of a foreign partner in a joint activity on creation of an innovative product under PPP, you can use the following basic formula:

$$
\mathrm{E}_{\text {ief }}=\mathrm{FR}_{\mathrm{f}} k_{1} k_{2} k_{3}-\mathrm{FR}_{\mathrm{d}},
$$

where $\mathrm{FR}_{\mathrm{f}}\left(\mathrm{NPV}_{\mathrm{f}}\right)$ - the expected financial results of the project to create an innovative product under the PPP with the involvement of international company; $k_{1}-$ coefficient of determining the scope of the project in the range [0,5:2]: 0.5 - municipal project, the total cost of the project up to $100 \mathrm{mln}$. rub.; 1 - regional project, cost from 100 to $500 \mathrm{mln}$. rub.; $1.5-$ regional or interregional project, cost from 500 million to 5 billion rubles.; 2 - a federal project cost more than 5 billion rubles; $k_{2}$ - coefficient that determines the level of business reputation (recognition) of a foreign (international) company attracted to cooperate in a project to create an innovative product under the PPP in the range [1:2]: 1 - the company is known (is recognized) in its country; 2 - the company is a world leader, cooperation with which bringes the highest reputational effect; $k_{3}$ - coefficient of the 
share of private capital in the project to create an innovative product under the PPP involving international company compared with domestic partner (as determined by the division of relevant shares); $\mathrm{FR}_{\mathrm{d}}\left(\mathrm{NPV}_{\mathrm{d}}\right)$ - the expected financial results of the project to create an innovative product under the PPP with the involvement of domestic company;

Calculation example. We assume that data is available: $\mathrm{FR}_{\mathrm{f}}-55 \mathrm{mln}$. rub.; project cost $1 \mathrm{bn}$. rub.; attracting foreign company which successfully operates in several countries, $k_{2}$ can be assessed at a rate of 1.5; the share of private capital in the project with the involvement of the international company $-55 \%$; the share of private capital in the project with the involvement of domestic company - $65 \%$; $\mathrm{FR}_{\mathrm{d}}-76 \mathrm{mln}$. rub.

In this case, the integral economic effect

$$
\begin{gathered}
\mathrm{E}_{\text {ief }}=55 \cdot 1.5 \cdot 1.5 \cdot 55 \% / 65 \%-76= \\
=28.71 \mathrm{mln} . \text { rub. }
\end{gathered}
$$

One should note that the calculation of the financial results of the implementation of innovative projects $\left(\mathrm{FR}_{\mathrm{f}}, \mathrm{FR}_{\mathrm{d}}\right)$ is of high uncertainty, only with the serious adjustments it is possible to use the individual data from the similar projects, if such data are applicable. To justify the statistical significance of relationships, which may be obtained for projects to develop innovative products under the PPPs with the involvement of the international company, one must have the data sets that reflect such experience. At present, such data is only partially available from the international practice of foreign companies in innovation projects under the PPP.

In addition, we should note that there is a possibility of supplementing the basic formula presented above with extra coefficients which would reflect the number of features an innovative project, which hasn't been taken into account, in particular: a) the industry of the project (does it belongs to a priority set of industries for innovative development in the country); b) the number of additional jobs created; c) the property rights on the results of an innovative project; g) the possibility of using the results of realization of the innovative project in the other projects and industries within the country and abroad, and others.
In this case, it is expedient to introduce an additional coefficient which takes into account a number of factors mentioned above on the balanced strength of their influence $-k_{\text {add }}$. As an alternative, it can be considered an integral coefficient taking into account the weighted influence on integral economic effect of the involvement of a foreign partner in a joint activity on creation of an innovative product in the PPP of all factors, including those that were represented by the coefficients $k_{1}-k_{3}$.

In this case, the formula (1) takes the form:

$$
\mathrm{E}_{\text {ief }}=\mathrm{FR}_{\mathrm{f}} k_{\text {int }}-\mathrm{FR}_{\mathrm{d}} \text {, }
$$

where $k_{\text {int }}-$ integral coefficient taking into account the weighted impact on integral economic effect of the involvement of a foreign partner in a joint activity on creation of an innovative product in the PPP extended set of factors.

$$
k_{\mathrm{int}}=\sum_{i=1}^{n} a_{i} b_{i},
$$

where $a_{i}$ - weight of $i$ characteristics (influence factor); $b_{i}$ - value of $i$ characteristics (influence factor).

Here is an example calculation of the integral factor. Let Krylov marine constructing bureau (Saint-Petersburg) as the coordinator of the PPP project is considering engaging in a joint project for the development of documentation and the creation of a prototype of high-tech equipment for the production of hydrocarbons on the Arctic shelf [39] three potential partners - from Russia (JSC «Central Research Institute of the Navy», JSC «Far Eastern center of shipbuilding and Ship Repair» (FECSR)), from China and the group of companies from Norway - Finland. Expert assessment of the impact of force, the importance (significance) of various factors (characteristics) in the project PPP potential partners on the integral gain and a comparison of the values of obtained integral coefficients are given in Tab. 2.

The calculation results in Tab. 2 show that for the partner from China produced results: $k_{\text {int }}=1,00375$, to partner group from Norway Finland $k_{\text {int }}=1,05625$. Next, to calculate the effect of the integral values of obtained $k_{\text {int }}$ should be substituted into the formula (2). 
Expert evaluation of the significance of the characteristics of participation in the PPP project ofP various partners and integral economic effect of the involvement of a foreign partner in a joint activity on creation of an innovative product under PPP

\begin{tabular}{|c|c|c|c|c|c|}
\hline № & $\begin{array}{c}\text { Features (factors) of innovative PPP projects that have } \\
\text { an impact on integral economic effect }\end{array}$ & $\begin{array}{l}\text { Rating of } \\
\text { the } \\
\text { characteristi } \\
\text { c, } \%\end{array}$ & $\begin{array}{l}\text { Partner } \\
\text { from } \\
\text { Russia }\end{array}$ & $\begin{array}{l}\text { Partner } \\
\text { from } \\
\text { China }\end{array}$ & $\begin{array}{l}\text { Partner } \\
\text { from } \\
\text { Norway } \\
\text { Finland }\end{array}$ \\
\hline 1 & 2 & 3 & 4 & 5 & 6 \\
\hline 1 & $\begin{array}{l}\text { level of business reputation (recognition) of a foreign or } \\
\text { domestic company attracted to cooperate in a project }\end{array}$ & 20 & 1 & 0,75 & 1,1 \\
\hline 2 & the share of private capital in the project & 15 & $\begin{array}{c}1 \\
(60 \%)\end{array}$ & $\begin{array}{l}1,125 \\
(65 \%)\end{array}$ & $\begin{array}{l}0,875 \\
(55 \%)\end{array}$ \\
\hline 3 & the number of additional jobs created & 12,5 & 1 & 1,2 & 1,3 \\
\hline 4 & $\begin{array}{l}\text { the property rights on the results of an innovative } \\
\text { project; }\end{array}$ & 12,5 & 1 & 0,9 & 0,8 \\
\hline 5 & $\begin{array}{l}\text { the possibility of using the results of realization of the } \\
\text { innovative project in the other projects and industries } \\
\text { within the country }\end{array}$ & 12,5 & 1 & 0,85 & 0,8 \\
\hline 6 & $\begin{array}{l}\text { the possibility of using the results of realization of the } \\
\text { innovative project in the other projects and industries } \\
\text { abroad }\end{array}$ & 12,5 & 1 & 1,15 & 1,3 \\
\hline 7 & $\begin{array}{l}\text { Communication effects of the involvement of specialists } \\
- \text { a partner in a joint operation }\end{array}$ & 15 & 1 & 1,15 & 1,2 \\
\hline & Total evaluation - integral coefficient $k_{i n t}$ & $100 \%$ & 1 & 1,00375 & 1,05625 \\
\hline
\end{tabular}

The results of the study. The following results were obtained within this work.

1. A model of public-private partnership system is drawn based on the background of causing one other economic growth factors that are related to the open communicative innovation economy. The model shows the appearance of axis «Communication» «partnership» - «innovation» - «development» on the basis of a long-term relationship of trust within the PPP between the subjects of the state and business. This relationship enhance the mutual dependence of subjects and the intensity of the exchange of information and thus become, communication - active. As part of the bunch «communication» - «partnership» the features of the mutual initiative in PPP-projects and the essential nature of PPP are described.

2. Based on the analysis of the features of partnership of the state and the private sector in a number of economies in the world it is revealed that the task of raising the level of involvement of private funds through PPP - of domestic and foreign investors - depends on quality installation to enhance the intensity of communication and inclusion of foreign partners in the innovative development programs.

3. As part of the quantitative determination of PPP impact on the communication environment of innovation economy an assessment of compliance is made of the functions ran by PPP centers operating today to the set of functions and features that are related to the concept of communication centers of innovation infrastructure.

4. The study suggests a method of calculation of the integrated economic effect from the involvement of foreign partners into the joint activity on creation of an innovative product under the PPP. It was concluded that such an effect will be one of particular indicators of the effectiveness of communication in innovation, which arises due to the international nature of cooperation within PPP. 
As the direction of future research the author sees the deepening of analysis of functions and competencies of existing innovation infrastructure subjects at the federal and regional levels, including the PPP centers, research and production centers of large companies, scientific-innovative centers at universities. Also there would be a need for a rationale for investment in the creation of additional structural units of existing innovation infrastructure subjects, or creating a special communication centers.

\section{REFERENCES}

1. Varnavskii V.G. Partnerstvo gosudarstva i chastnogo sektora: formy, proekty, riski. M.: Nauka, 2010. (rus)

2. Gosudarstvenno-chastnoe partnerstvo v innovatsionnoi sfere: mirovoi opyt i perspektivy Rossii. Pod red. R.M. Nizhegorodtseva, S.M. Nikitenko, E.V. Goosen. Kemerovo: Sibirskaia izdatel'skaia gruppa, 2012. 482 s. (rus)

3. Kazantsev A.K., Rubval'ter D.A. Gosudarstvennochastnoe partnerstvo $\mathrm{v}$ nauchno-innovatsionnoi sfere. M: Infra-M, 2015. 330 s. (rus)

4. Kireeva A.V., Khud'ko E.V., Sokolov I.A., Tishchenko T.V. Gosudarstvenno-chastnoe partnerstvo kak instrument podderzhki innovatsii. Pod red. I.A. Sokolova. M.: Izd. dom «Delo» RANKhiGS, 2012. 514 s. (rus)

5. Delmon J. Understanding Options for PublicPrivate Partnerships in Infrastructure. Sorting Out the Forest from the Trees. World Bank, Washington DC, Policy Research Working Paper 5173, January 2010.

6. Delmon J. Private Sector Investment in Infrastructure: Project Finance, PPP Projects and Risk. The World Bank and Kluwer Law lnternational, 2009. $600 \mathrm{r}$.

7. Public Private Partnership: Ein Leitfaden fur offentliche Verwaltunguud Unternehmer (Dokumentation). Bundesministerium fur Wirtschaft und Arbeit. 2009.

8. Mochal'nikov V. Gosudarstvenno-chastnoe partnerstvo. Otechestvennyi opyt, mirovye tendentsii, vektor razvitiia dlia Rossii. M.: Ekonomika, 2012. 352 s. (rus)

9. Emel'ianov Iu.S. Gosudarstvenno-chastnoe partnerstvo. Innovatsii i investitsii. Mirovoi i otechestvennyi opyt. M.: Librokom, 2013. 368 s. (rus)

10. Makhovikova G.A., Efimova N.F. Gosudarstvenno-chastnoe partnerstvo: zarubezhnyi opyt i rossiiskie realii. SPb.: Izd-vo SPbGEU, 2013. 251 s. (rus)

11. Ieskomb E. Gosudarstvenno-chastnoe partnerstvo: Osnovnye printsipy finansirovaniia. M.: Al'pina pablisher, 2015. 457 s. (rus)

12. Babkin I.A., Zherebov E.D. The mechanism of interaction between government and business on the basis of state-private partnership. St. Petersburg State Polytechnical University Journal. Economics, 2015, no. 4(223), pp. 99-107. DOI: 10.5862/JE.223.9 (rus)

13. Razvitie gosudarstvenno-chastnogo partnerstva v regionakh TsFO: investitsii i infrastruktura. - otchet po rezul'tatam issledovaniia Tsentra GChP i Instituta sovremennogo razvitiia. M., 2010. URL: http://pppcenter.ru/assets/files/Anons/a_CFO\%203.p df (data obrashcheniia: 21.07.2016).

14. Radushinskii D.A. Osobennosti realizatsii soglashenii o gosudarstvenno-chastnom partnerstve $\mathrm{V}$ innovatsionnoi sfere. Peterburgskii ekonomicheskii zhurnal. 2016. № 2. S. 70-78. (rus)

15. Gelbreit Dzh.K. Novoe industrial'noe obshchestvo. Izbrannoe. M.: Eksmo, 2008, 1200 s. (rus)

16. The Knowledge-based Economy. Paris, OECD, 1996.

17. Lopez-Martinez E., Piccaluga A. Knowledge Flows in National Systems of Innovation. Cheltenham, Edward Elgar, 2000.

18. New economy: innovation insight into Russia / Center of Strategic Partnership. Moscow, LigaPrint. 2008. 223 p.

19. Lundvall B. National Systems of Innovation: Toward a Theory of Innovation and Interactive Learning. New York, Anthem Press, 2010.

20. Lee K. Schumpeterian Analysis of Economic Catch-up: Knowledge, Path-creation, and the Middleincome Trap. Cambridge, Cambridge University Press, 2013.

21. Institut Vsemirnogo banka. K4D. Znaniia dlia razvitiia. Izmerenie znanii $v$ ekonomikakh mira. URL: http://siteresources.worldbank.org/INTUNIKAM/

Resources/KAM_v4.2015.pdf (data obrashcheniia: 05.10.2016) (rus); Chen Derek H.C., Dahlman Carl J. The knowledge economy, the KAM methodology and World Bank operations. Washington, DC: World Bank, 2006. http://documents.worldbank.org/curated /en/695211468153873436/ The-knowledge-economythe-KAM-methodology-and-World-Bank-operations. 42 p. (accused October 05, 2016).

22. Naumov V.N., Sharapova O.A. Formirovanie vospriiatiia sobstvennoi torgovoi marki roznichnogo predpriiatiia. Brend-Menedzhment. 2009. № 1. S. 28-35. (rus)

23. Global'nyi indeks konkurentosposobnosti «Global Competitiveness Index» (GCI) Vsemirnogo ekonomicheskogo foruma. URL: http://reports.weforum. org/global-competitiveness-report-2015-2016/competi tiveness-rankings/ (data obrashcheniia: 29.07.2016). (rus) 
24. Global'nyi innovatsionnyi indeks «Global innovation index» (GII). URL: https://www.globalin novationindex.org/gii-2015-report (accussed July 29, 2016).

25. Reiting Doing Business - issledovanie, provodimoe Vsemirnym bankom i Mezhdunarodnoi finansovoi korporatsiei. URL: http://www.doingbusin ess.org/rankings (data obrashcheniia: 29.07.2016). (rus)

26. Airapetian M.S. Zarubezhnyi opyt ispol'zovaniia gosudarstvenno-chastnogo partnerstva. URL: http:// iam.duma.gov.ru/node/8/4669/16628 (data publikatsii: 12.2008). (rus)

27. Repko M., Piontkovskaia I., Kukhta P. Kakoi dolzhna byt' dolia gosudarstva $\mathrm{v}$ ekonomike? - URL: http://economics.lb.ua/state/2015/12/08/322795_kako y_dolzhna_dolya_gosudarstva.html (data publikatsii: $08.12 .2015)$. (rus)

28. Koroleva A.I., Babkin I.A. Elements of public_private partnership as a mechanism innovation economy. St. Petersburg State Polytechnical University Journal. Economics, 2013, no. 1-1(163), pp. 31-38. (rus)

29. Tishchenko T. Gosudarstvennyi biudzhet. URL: http://www.iep.ru/files/RePEc/gai/ruserr/515Tis hchenko.pdf (data obrashcheniia: 10.08.2016). (rus)

30. Larina S.E. Obshchee i osobennoe v razvitii biudzhetnoi detsentralizatsii. Vestnik AGU. 2013. № 4(131). URL: http://vestnik.adygnet.ru/files/ 2013.4 /3082/46-55.pdf (data obrashcheniia: 10.08.2016). (rus)

31. Reiting regionov Rossii po urovniu razvitiia gosudarstvenno-chastnogo partnerstva 2014-2015. M.: Tsentr razvitiia GChP, 2016. URL: http://pppi.ru/sites /default/files/docs/rating2016.pdf (data obrashcheniia: 08.08.2016). (rus)

32. Gordenko G.V. Gosudarstvenno-chastnoe partnerstvo $\mathrm{v}$ innovatsionnoi sfere: perspektivy razvitiia v Rossii. Modernizatsiia Rossii: kliuchevye problemy $i$ resheniia : mater. XIII Mezhdunar. nauch. konf.
(Moskva, 20-21 dekabria 2012 g.). M., 2013. URL: http://www.gosbook.ru/node/72995 (data obrashcheniia: 14.08.2016). (rus)

33. Shlafman A.I. The Genesis of the integration processes in the economy of the Russian Federation: the problem of cyclicity and state regulation. St.Petersburg State Polytechnical University Journal. Economics, 2013, no. 6(185), pp. 39-47. (rus)

34. Praktika primeneniia kontsessionnykh soglashenii dlia razvitiia regional'noi infrastruktury $\mathrm{v}$ Rossii. Ministerstvo ekonomicheskogo razvitiia Rossiiskoi Federatsii. M., 2014. URL: http://economy. gov.ru/minec/activity/sections/privgovpartnerdev/ 2014112710 (data obrashcheniia: 21.07.2016). (rus)

35. O kontsessionnykh soglasheniiakh: Federal'nyi zakon Rossiiskoi Federatsii № 115-FZ ot 21.07.2005 g. (red. 30.12.2015 g.). SPS «Konsul'tantPlius». (rus)

36. O gosudarstvenno-chastnom partnerstve, munitsipal'no-chastnom partnerstve $\mathrm{v}$ Rossiiskoi Federatsii i vnesenii izmenenii $v$ otdel'nye zakonodatel'nye akty Rossiiskoi Federatsii (Zakon o GChP): Federal'nyi zakon Rossiiskoi Federatsii № 224-FZ ot 13.07.2015 g. (red. 03.07.2016 g.). SPS «Konsul'tantPlius». (rus)

37. Afontsev S.A. Vykhod iz krizisa v usloviiakh sanktsii: missiia nevypolnima? URL: http://institutio nes.com/general/2562-vyxod-iz-krizisa-v-usloviyaxsankcij.html (data obrashcheniia: 12.08.2016). (rus)

38. Radoushinsky D.A., Zdolnikova S.V. Communication centers as an element of the institutional environment of innovative economy. St.Petersburg State Polytechnical University Journal. Economics, 2015, no. 5(228), pp. 54-63. DOI: 10.5862/JE.228.5

39. Borodin V.V., Vas'kov N.N., Kalistratov N.Ia. i dr. O sozdanii i razvitii spetsializirovannoi verfi «Arktika - shel'f». Arktika i Sever. 2014. № 17. S. 1421. (rus)

\section{СПИСОК ЛИТЕРАТУРЫ}

1. Варнавский В.Г. Партнерство государства и частного сектора: формы, проекты, риски. М.: Наука, 2010.

2. Государственно-частное партнерство в инновационной сфере: мировой опыт и перспективы России / под ред. Р.М. Нижегородцева, С.М. Никитенко, Е.В. Гоосен. Кемерово: Сибирская издательская группа, 2012. 482 с.

3. Казанцев А.К., Рубвальтер Д.А. Государственно-частное партнерство В научноинновационной сфере. М: Инфра-М, 2015. 330 с.

4. Киреева А.В., Худько Е.В., Соколов И.А., Тищенко Т.В. Государственно-частное партнерство как инструмент поддержки инноваций / под ред. И.А. Соколова. М.: Изд. дом «Дело» РАНХиГС, 2012. 514 c.
5. Delmon J. Understanding Options for PublicPrivate Partnerships in Infrastructure. Sorting Out the Forest from the Trees. World Bank, Washington DC, Policy Research Working Paper 5173, January 2010.

6. Delmon J. Private Sector Investment in Infrastructure: Project Finance, PPP Projects and Risk. The World Bank and Kluwer Law International, 2009. 600 p.

7. Public Private Partnership: Ein Leitfaden fur offentliche Verwaltunguud Unternehmer (Dokumentation) // Bundesministerium fur Wirtschaft und Arbeit. 2009.

8. Мочальников В. Государственно-частное партнерство. Отечественный опыт, мировые тенденции, вектор развития для России. М.: Экономика, 2012. 352 с.

9. Емельянов Ю.С. Государственно-частное партнерство. Инновации и инвестиции. Мировой 
и отечественный опыт. М.: Либроком, 2013. $368 \mathrm{c}$.

10. Маховикова Г.А., Ефимова Н.Ф. Государственно-частное партнерство: зарубежный опыт и российские реалии. СПб.: Изд-во СПбГЭУ, 2013. 251 с.

11. Йескомб Э. Государственно-частное партнерство: Основные принципы финансирования М.: Альпина паблишер, 2015. 457 с.

12. Бабкин И.А., Жеребов Е.Д. Механизм взаимодействия государства и бизнеса на основе государственно-частного партнерства // Научнотехнические ведомости Санкт-Петербургского государственного политехнического университета Экономические науки. 2015. № 4(223). С. 99-107. DOI: 10.5862/JE.223.9

13. Развитие государственно-частного партнерства в регионах ЦФО: инвестиции и инфраструктура. - отчет по результатам исследования Центра ГЧП и Института современного развития. M., 2010. URL: http://pppcenter.ru/assets/files/Anon s/a_CFO\%203.pdf (дата обращения: 21.07.2016).

14. Радушинский Д.А. Особенности реализации соглашений о государственно-частном партнерстве в инновационной сфере // Петербургский экономический журнал. 2016. № 2. С. 70-78.

15. Гелбрейт Дж.К. Новое индустриальное общество. Избранное. М.: Эксмо, 2008, 1200 с.

16. The Knowledge-based Economy. Paris: OECD, 1996.

17. Lopez-Martinez E., Piccaluga A. Knowledge Flows in National Systems of Innovation. Cheltenham, Edward Elgar, 2000.

18. New economy: innovation insight into Russia / Center of Strategic Partnership. Moscow: Liga-Print. 2008. 223 p.

19. Lundvall B. National Systems of Innovation: Toward a Theory of Innovation and Interactive Learning. New York: Anthem Press, 2010.

20. Lee K. Schumpeterian Analysis of Economic Catch-up: Knowledge, Path-creation, and the Middle-income Trap. Cambridge: Cambridge University Press, 2013.

21. Институт Всемирного банка. K4D. Знания для развития. Измерение знаний в экономиках мира. URL: http://siteresources.worldbank.org/INT UNIKAM/ Resources/KAM_v4.2015.pdf (дата обращения: 05.10.2016); Chen Derek H.C., Dahlman Carl J. The knowledge economy, the KAM methodology and World Bank operations. Washington, DC: World Bank, 2006. http://documents.worldbank.org/ curated/en/695211468153873436/The-knowledgeeconomy- the-KAM-methodology-and-World-Bankoperations, 42 р. (дата обращения: 05.10.2016).

22. Наумов В.Н., Шарапова О.А. Формирование восприятия собственной торговой марки розничного предприятия // Бренд-Менеджмент. 2009. № 1. С. $28-35$.
23. Глобальный индекс конкурентоспособности «Global Competitiveness Index» (GCI) Всемирного экономического форума. URL: http://reports. weforum.org/global-competitiveness-report-2015-2016/ competitiveness-rankings/ (дата обрашения: 29.07.2016).

24. Глобальный инновационный индекс «Global innovation index» (GII). URL: https://www. globalinnovationindex.org/gii-2015-report (дата обращения: 29.07.2016).

25. Рейтинг Doing Business - исследование, проводимое Всемирным банком и Международной финансовой корпорацией. URL: http://www. doingbusiness.org/rankings (дата обрашения: 29.07.2016).

26. Айрапетян М.С. Зарубежный опыт использования государственно-частного партнерства. URL: http://iam.duma.gov.ru/node/8/4669/16628 (дата публикации: 12.2008).

27. Репко М., Пионтковская И., Кухта П. Какой должна быть доля государства в экономике? URL: http://economics.lb.ua/state/2015/12/08/32279 5_kakoy_dolzhna_dolya_gosudarstva.html (дата публикации: 08.12.2015).

28. Королева А.И., Бабкин И.А. Элементы государственно-частного партнерства как механизма инновационного развития экономики // Научнотехнические ведомости Санкт-Петербургского государственного политехнического университета. Экономические науки. 2013. № 1-1(163). С. 31-38.

29. Тищенко Т. Государственный бюджет. URL: http://www.iep.ru/files/RePEc/gai/ruserr/515Ti shchenko.pdf (дата обращения: 10.08.2016).

30. Ларина С.Е. Общее и особенное в развитии бюджетной децентрализации // Вестник АГУ. 2013. № 4(131). URL: http://vestnik.adygnet.ru/files/ 2013.4/3082/46-55.pdf (дата обращения: 10.08.2016).

31. Рейтинг регионов России по уровню развития государственно-частного партнерства 20142015. М.: Центр развития ГЧП, 2016. URL: http://pppi.ru/sites/default/files/docs/rating2016.pdf (дата обращения: 08.08.2016).

32. Горденко Г.В. Государственно-частное партнерство в инновационной сфере: перспективы развития в России // Модернизация России: ключевые проблемы и решения : матер. XIII Meждунар. науч. конф. (Москва, 20-21 декабря 2012 г.). M., 2013. URL: http://www.gosbook.ru/node/72995 (дата обращения: 14.08.2016).

33. Шлафман А.И. Генезис интеграционных процессов в экономике Российской Федерации: проблемы цикличности и государственного регулирования // Научно-технические ведомости Санкт-Петербургского государственного политехнического университета. Экономические науки. 2013. № 6(185). С. 39-47.

34. Практика применения концессионных соглашений для развития региональной инфра- 
структуры в России / Министерство экономического развития Российской Федерации. М., 2014. URL: http:/economy.gov.ru/minec/activity/sections/ privgovpartnerdev/ 2014112710 (дата обращения: 21.07.2016).

35. О концессионных соглашениях: Федеральный закон Российской Федерации № 115-Ф3 от 21.07.2005 г. (ред. 30.12.2015 г.) // СПС «КонсультантПлюс».

36. О государственно-частном партнерстве, муниципально-частном партнерстве в Российской Федерации и внесении изменений в отдельные законодательные акты Российской Федерации (Закон о ГЧП): Федеральный закон Российской Федерации № 224-Ф3 от 13.07.2015 г. (ред.
03.07.2016 г.) // СПС «КонсультантПлюс».

37. Афонцев C.А. Выход из кризиса в условиях санкций: миссия невыполнима? URL: http://inst itutiones.com/general/2562-vyxod-iz-krizisa-v-usloviya $\mathrm{X}$-sankcij.html (дата обращения: 12.08.2016).

38. Радушинский Д.А. Коммуникационные центры как элемент институциональной среды инновационной экономики // Научно-технические ведомости Санкт-Петербургского государственного политехнического университета. Экономические науки. 2015. № 5(228). C. 54-63. DOI: 10.5862/JE.228.5

39. Бородин В.В., Васьков Н.Н., Калистратов Н.Я. и др. О создании и развитии специализированной верфи «Арктика - шельф»// Арктика и Север. 2014. № 17. C. 14-21.

RADOUSHINSKY Dmitrii A. - St. Petersburg State Forestry Engineering University named after S.M. Kirov.

195251. Insitutskiy av. 5. St. Petersburg. Russia. E-mail: d.radoushinsky@gmail.com

РАДУШИНСКИЙ Дмитрий Александрович - доцент кафедры Санкт-Петербургского государственного лесотехнического университета им. С.М. Кирова, кандидат экономических наук.

195251, Институтский пр., д. 5, Санкт-Петербург, Россия. E-mail: d.radoushinsky@gmail.com 